DOI: 10.46340/eppd.2020.7.3.24

Oleksii Kokoriev

ORCID ID: https://orcid.org/0000-0001-7391-2498

College of Telecommunication and Informatization of ONAT named after A.S. Popov, Ukraine

\title{
PROBLEMS OF THE QUALITY OF LITHUANIAN DEMOCRACY: THE INFLUENCE OF POPULISM AND THE VARIABILITY OF THE PARTY LANDSCAPE
}

\author{
Олексій Кокорєв \\ Попова, Україна

\section{ПРОБЛЕМИ ЯКОСТІ ДЕМОКРАТІЇ ЛИТВИ: ВПЛИВ ПОПУЛІЗМУ ТА МІНЛИВОСТІ ПАРТІЙНОГО ЛАНДШАФТУ}

Коледж зв'язку та інформатизації Одеської національної академії зв'язку ім. О. С.

\begin{abstract}
The issue of the quality of democracy in Lithuania has been studied. Attention is focused on the period after Lithuania's accession to the EU. It has been clarified how popular populism, radicalism, Euroscepticism, and socio-political phobias are in the politics of this country. The peculiarities of the political and legal culture of Lithuanians in terms of its compliance with European liberal-democratic values are studied. It is noted that although Lithuania is now part of the group of consolidated democracies, the low level of trust of Lithuanians in the main political institutions indicates the growing defects of democracy. Emphasis is placed on the expansion of populist rhetoric in Lithuania over the last decade. It is noted that the defects of democracy in Lithuania are manifested in uncivilized lobbying, corruption, intolerance of minorities, and hate speech. The deepening of democracy defects in Lithuania is projected against the background of rising socio-economic problems as a result of the global COVID-19 pandemic.
\end{abstract}

Keywords: Lithuania, liberal democracy, populism, radicalism.

Литва має давні демократичні традиції, починаючи від елементів демократичного устрою періоду Великого князівства Литовського, що увиразнено, наприклад, у Литовських статутах XVI століття. У новітній період країна для досягнення мети вступу до ЄС пройшла складний шлях виконання важливих вимог у частині демократизації (Копенгагенські критерії). Про зорієнтованість литовців на ліберально-демократичні цінності свідчить схвалення більшістю з них вступу країни до СС (71\%), позиціювання себе громадянами СС (77\%); ці показники перевищують середні значення по СС (61 і 71\% відповідно) ${ }^{1}$. Висока підтримка литовцями європейських цінностей була продемонстрована ще в ході референдуму 2003 року про підтримку вступу Литви до ЄС, коли 91\% тих, хто віддав свій голос, проголосували «за» євроінтеграцію.

Настрої євроскептицизму, популізму, радикалізму і под. не $\epsilon$ виражені в Литві, однак на постінтеграційному етапі неоліберальна демократія у цій країні проходить випробування на стійкість. Увиразнилася низка викликів для ефективного функціонування ліберальнодемократичних інститутів, очевидними є невідповідності політико-правової культури населення ліберально-демократичній моделі, на яку зорієнтований СС.

Дані звітів Freedom House «Нації у транзиті» за кілька останніх років дозволяють зробити висновок про стагнацію Литви у просуванні ліберально-демократичних цінностей. Наразі Литва (як і Естонія та Латвія) залишається в групі консолідованих демократій, але іiі досягнення не мають

${ }^{1}$ Standartinis Eurobarometras 90. Šalies ataskaita. Lietuva. Visuomenès nuomoné Europos Sajungoje (2018).

$<$ file://D:/Media/Downloads/eb90_nat_lt_lt.pdf> (2020, травень, 17). 
висхідної динаміки: 2017 рік - 78 балів, 2018-2020 роки - по 77 балів. Втім, безумовним позитивом у ситуації загальнопланетарної кризи демократії $є$ те, що усі країни Балтії, на противагу багатьом «молодим демократіям» $Є$, наразі втримуються на позиціях консолідованих демократій.

Про наявність дефектів демократії свідчить, найперше, низький рівень довіри литовців владі, основним інститутам політики. За результатами опитування (березень 2020 р.), проведеного литовською інституцією з вивчення громадської думки UAB Vilmorus, лише 7,5\% респондентів довіряють політичним партіям, 10,6\% - Сейму, 24,9\% - судам ${ }^{1}$. Для порівняння: $89,8 \%$ опитаних висловили довіру пожежно-рятувальній службі, $68,6 \%$ - поліції ${ }^{2}$.

За результатами опитування громадської думки (дослідження компанії UAB Baltijos tyrimai, проведене 13-26.02.2020 p. ${ }^{3}$ ) інституту демократії не довіряли майже половина населення Литви: $47 \%$ опитаних скептично оцінили, як працює демократія в їх державі. Наголосимо: йдеться не про недовіру демократії як формі політичної організації суспільства, а про невдоволеність тим, як вона працює на національному рівні в конкретній країні. Більше задоволених функціонуванням демократичних інститутів у Литві $\epsilon$ серед молоді до 30 років, жителів столиці, респондентів 3 вищою освітою, жіноцтва; менш задоволеними $є$ чоловіки, особи, старші 50 років, селяни, особи 3 щомісячним сімейним доходом нижче 700 євро, пенсіонери, безробітні, домогосподарки, представники російської та польської національних меншин.

На якість демократії впливає рівень впливу популістів і радикальних політичних сил на політику країни, їх представленість в органах влади. Наразі популістські та радикальні політичні сили не проявили значного впливу в Литві, на відміну від багатьох «молодих демократій» СС. Кейс Литви, як правило, не включають у політологічний дискурс про європейський популізм і екстремізм 3 огляду на їх незначну увиразненість на тлі яскравих проявів в інших країнах СС. Однак не можна ігнорувати той факт, що близько третини голосів на парламентських виборах литовський електорат віддає за популістські партії ${ }^{4}$. Попри відсутність глибокої традиції популізму в Литві, в останнє десятиліття все ж відбулося розширення популістської риторики.

У новітній період елементи популізму були характерні, найперше, громадсько-політичному руху «Саюдіс» (Sajūdis), який виступав рушійною силою боротьби Литви за незалежність. Новий імпульс популізму в Литві був даний на початку XXI століття ${ }^{5}$. Проявом цього стало обрання (2003 р.) завдяки, не в останню чергу, популістській риториці на посаду глави держави Р. Паксаса (усунутий в порядку імпічменту 06.04.2004 р.) попри наявність гідного електорального конкурента вираженого єврооптиміста, зрілого політика В. Адамкуса. Створена з ініціативи Р. Паксаса у 2002 році партія «Порядок і справедливість» (Tvarka ir teisingumas) незмінно підтримується литовськими виборцями (2004, 2008, 2012 та 2016 рр.). Дискурс партії «Порядок і справедливість» не $\epsilon$ націоналістичним ${ }^{6}$, а тому виправданим $є$ віднесення цієї політичної сили до центристського популізму ${ }^{7}$. Попри те, що «Порядок і справедливість» вже чотири рази поспіль представлена в Сеймі, iї популярність істотно знизилася після доведення причетності до політичної корупції (протекціонізму).

\footnotetext{
${ }^{1}$ Відзначимо, що в попередні місяці рівень довіри до згаданих інститутів (за замірами UAB Vilmorus) залишався приблизно таким же. Тобто, додаткові соціально-економічні проблеми унаслідок пандемії COVID-19 не стали чинником різкого зниження рівня довіри литовців до владних інститутів, а проблеми кризи легітимності влади існують давно.

${ }^{2}$ Tyrimo. Ar Jūs pasitikite, ar nepasitikite šiomis Lietuvos institucijomis? (2020).

$<$ http:/www.vilmorus.lt/index.php?mact=News,cntnt01,detail,0\&cntnt01 articleid=2\&cntnt01 returnid=20> (2020, квітень, 29).

${ }^{3}$ Jaruševičiūtè, G. (2020). Reitingai: pasitikejjimas demokratija šalyje paaugo, tačiau vis dar išlieka žemas. $<$ https:/www.delfi.lt/news/daily/lithuania/reitingai-pasitikejimas-demokratija-salyje-paaugo-taciau-vis-dar-isliekazemas.d?id=83771521> (2020, квітень, 19).

${ }^{4}$ Aleknonis, G., Matkevičienè, R. (2016). Populism in Lithuania: defining the research tradition. Baltic Journal of Law \& Politics, 9 (1), 28.

${ }^{5}$ Pabiržis, D. (2013). Populistinès ideologijos partijos Baltijos šalyse 2011-2012 m. Politikos mokslu almanachas, 14, 121.

${ }^{6}$ Ramonaitè, A., Ratkevičiūtè, V. (2013). The Lithuanian Case: National Populism Without Xenophobia. In: Exposing the Demagogues: Right-Wing and National Populist Parties in Europe. Berlin: KAS, 264.

${ }^{7}$ Романюк, А.С., Литвин, В.С., Панчак-Бялоблоцка, Н.В. (2014). Політичні інститути краӥн иеентральносхідної Європи: порівняльний аналіз. Львів: Львівський національний університет імені Івана Франка, 232.
} 
Ще один популістський а́ктор - політична партія «Шлях мужності» (Drąsos Kelias) - увійшла до складу Сейму за результатами виборів 2012 року. Вона здобула 7 мандатів, хоча була створена лише за кілька місяців до цих виборів. Такі факти слугують маркерами для оцінки політичної культури литовців, наявності у них стійких електоральних преференцій. Водночас втримати чи збільшити свій вплив на литовську політику ця партія не зуміла, а відтак вже на наступних виборах 2016 року не отримала необхідної для проходження до парламенту підтримки електорату.

На парламентських виборах 2016 року такі популістські а́ктори, як Литовська народна партія, партія «Молода Литва» та Союз литовських націоналістів ${ }^{1}$ (об’єднані в коаліцію С. Бушкевічюса та націоналістів «Проти корупції та бідності») не подолали прохідний бар'єр. Так само не подолала його й «Партія праці» (до Сейму пройшли лише два кандидати в мажоритарних округах). Литовські політологи ${ }^{2}$ відносять до популістських також такі партії та рухи з антисистемною спрямованістю, як партія «Список Литви» («Lietuvos sąrašas»), Об’єднаний демократичний pyx (Jungtinis Demokratinis Judejjimas), громадянський рух «Разом» («Kartu»)

Прихід у 2016 році до влади опозиційного Литовського союзу селян і зелених (LVŽS; 56 зі 141 місця в Сеймі) став переходом Литви до нового, консервативного, політичного порядку денного. Консервативна позиція LVŽS, найперше, проявляється в християнсько-зорієнтованому підході до шлюбу та сім'ї, збереженні національної ідентичності тощо. Водночас партія за чотири роки перебування при владі не ініціювала радикальних перетворень, як, до прикладу, польська керівна партія PiS, яка виступила за законодавче закріплення звуження сексуальних і репродуктивних прав (обмеження доступу до абортів, криміналізацію популяризації сексуальної освіти в освітніх установах та за їх межами), а також озвучила низку інших ініціатив, які суперечать ліберальнодемократичному курсу (C). Також відзначимо, що партія LVŽS фактично оминула у своїх виборчій кампанії та подальшій парламентській діяльності питання прав ЛГБТІ-спільноти, з огляду на те, що в середовищі партії наявні розбіжності щодо прийнятності інституту цивільного партнерства, зокрема й для одностатевих пар (як це $є$ в Естоніï). LVŽS, з одного боку, ставить завданням просувати консервативні цінності щодо шлюбу та сім'ї, однак, з іншого - не стає радикальною платформою для обговорення цієї теми. Отже, попри консервативно-зорієнтований курс керівної партії LVŽS, Литві наразі вдавалося уникати різкого наростання дефектів ліберальної демократії.

Зауважимо, що від 1996 року жодна політична партія Литви не мала більше 40-а місць у парламенті. Падіння рейтингу попередньої керівної партії (Соціал-демократична партія Литви, LSDP) було пов'язано з корупційними викриттями. Не виключено, що перемога на виборах 2016 року такої нової партії, як LVŽS, була пов'язана зі загальноєвропейською тенденцією наростання популізму, коли розчаровані виборці шукали «нових облич» у політиці. LVŽS акцентувала на технократичному уряді професіоналів і громадських діячів, які прийдуть 3-поза партійного середовища.

Однак нинішній рівень довіри литовців до уряду ставить під сумнів подальшу електоральну підтримку литовцями LVŽS, тобто пошук «нових облич» у політиці продовжуватиметься. Це очевидно з огляду на те, що під вибори 2020 року було ініційовано інституціоналізацію кількох нових литовських політичних партій. Наприклад, утворена (лютий 2020 р.) партія «Християнський союз» (Krikščionių sajungą) - права політична сила, яка не задекларувала євроскептицизм, однак висловила незгоду з гендерною, шлюбно-сімейною політикою ЄС. Ще однією новоствореною (березень 2020 р.) правою партією є Національний союз (Nacionalinis susivienijimas); ця політична сила наголошує на важливості національного питання, цінностей християнської цивілізації, виступає проти поглиблення інтеграції Литви з ЄС. Відтак очевидною є сильна турбулентність партійної системи Литви - чергові вибори неодмінно пов'язані з появою нових політичних партій, розпадом старих партій, утворенням нових союзів тощо. Це посилює недовіру литовців до політичних партій та формування їх іміджу як деструктивних акторів.

Повертаючись до керівної нині партії LVŽS, відзначимо, що вона $є$ увиразненням новітнього центристського популізму. Політичні актори, які репрезентують цей різновид популізму, «не $є$

\footnotetext{
${ }^{1}$ Союз литовських націоналістів є доволі маргінальною партією і гасло партії «Lietuva lietuviams» («Литва - для литовців») вочевидь не користується великою прихильністю громадськості, позаяк партія не $\epsilon$ представлена у парламенті.

${ }^{2}$ Stašienè, J. (2016). Populist Discourse on Political Representation: A Case Study of Anti-Establishment Organizations in Lithuania. Baltic Journal of Political Science, 5, 58.
} 


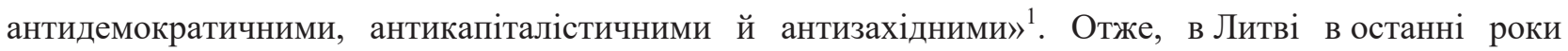
керівну позицію все ж займали популісти, однак помірні, центристські з легкою правою зорієнтованістю. Завдяки цьому литовська політика досі відчутно не радикалізувалася, відсутнє стрімке наростання дефектів ліберальної демократії. Водночас необхідно враховувати, що Литва має сприятливі передумови для формування впливових популістських, праворадикальних політичних акторів: великі етнічні меншини, консерватизм населення, історична традиція тощо ${ }^{2}$.

Також останніми роками в Литві помітна активізація різноманітних протестних націоналістичних а́кторів. Хоч праворадикальний рух в Литві й не можна вважати сильним, однак його акції підривають стійкість Литви як держави, яка зобов'язана з огляду на членство в СС утверджувати ліберально-демократичні цінності. Прикладом наведемо незареєстровану партію Литовський національний союз (LITAS) - радикальну неонацистську політичну силу, яка своїми діями розпалює ненависть, пропагує расизм i антисемітизм. Ще одним активним праворадикальним актором у Литві нині $\epsilon$ етнофутуристичний молодіжний pyx «Kryptis». Прикладом їх діяльності може слугувати проведення (15.02.2019р.) резонансної конференції «Prabudimas» у Вільнюсі за участю представників радикальних, екстремістських рухів 3 різних країн, які перебувають на позиціях «білого» націоналізму, антисемітизму, неонацизму. Такі заходи $\epsilon$ яскравим проявом мови ненависті, які потребують невідкладного реагування правоохоронних та судових органів Литви. Втім, видається, що інститут держави не розглядає такі політичні сили як потенційну загрозу демократичній державності Литви, а основну небезпеку вбачає зі сторони Російської Федерації³.

Акцентуємо, що крайні праві політичні сили досі не проходили до Сейму та залишаються на маргінесі політичного життя Литви. У Литві періодично відбуваються події за участю радикальних політичних сил, в ході яких фіксуються прояви антисемітизму, неорасизму, неонацизму, ксенофобії, антимігрантські настрої. Основним проявом активізації крайніх правих політичних а́кторів Литви $є$ щорічні акції з відзначення пам'ятних дат, пов'язаних з незалежністю держави (16 лютого, 11 березня).

Якщо ж звернутися до виборів глави Литовської Республіки, то у ході президентської виборчої кампанії 2019 року громадськість підтримала проєвропейського кандидата Г. Науседу. Показово, що й інша кандидатка, яка вийшла в другий тур цих виборів, I. Шимоніте, також перебуває на проєвропейських правоцентристських позиціях, дистанційованих від популізму та радикалізму. Обидва найактивніше підтримувані кандидати на посаду президента Литовської Республіки вигідно контрастували з рештою кандидатів, котрих більшою чи меншою мірою характеризував євроскептицизм, етнонаціоналізм, популізм і под. Підтримка таких кандидатів електоратом слугує аргументом прихильності значної частини литовців до ліберальнодемократичних цінностей. Відтак перспектива різкого зростання в Литві впливу ліво- чи правопопулістських сил $є$ малоймовірною, однак центристський популізм перебуває на висхідній позиції й ініціативи таких акторів можуть також мати значний деструктивний вплив.

Прикладом вищесказаного слугує спроба перегляду виборчої системи Литви, зроблена наприкінці 2019 року. Наразі прохідний бар'єр (за змішаної виборчої системи) становить 5\% для партій та 7\% - для коаліцій. Партії з нині керівної коаліції 4 ініціювали зниження його зниження до 3\% для партій і 5\% для коаліцій. Законопроєкт отримав підтримку Сейму, однак глава держави Г. Науседа наклав на нього вето, яке парламент не зумів подолати. Вважаємо, що ініційоване зниження прохідного бар'єра могло слугувати погіршенню якості демократії в Литві, адже ця країна і так має один із найбільш роздроблених в Європі парламентів. Проблемою Литви також $є$ те, що кожен наступний новообраний склад Сейму характеризується значною ротацією депутатів - щоразу обирається велика кількість політиків з нових політичних сил і відсутністю досвіду роботи в парламенті.

\footnotetext{
${ }^{1}$ Литвин, В. (2012). Популістські партії у структурі модерних партійних систем країн Центральної Європи: порівняльний аналіз. Освіта регіону: політологія, психологія, комунікаиії, 2, 72.

${ }^{2}$ Осколков, П.В. (2019). Правый популизм в Европейском союзе. Москва: Институт Европы РАН, 112-113.

${ }^{3}$ The National Security Threat Assessment (2020). Vilnius: Second Investigation Department under the Ministry of National Defence (AOTD) and the State Security.

${ }^{4}$ Литовський союз селян та зелених, партія «Порядок і справедливість», Виборча акція поляків - Союз християнських родин, Соціал-демократична партія Литви.
} 
Якщо прихильники зниження прохідного бар'єра розцінювали такі зміни як свідчення зрілої демократії, то противники образно порівнювали їх з троянським конем, призначеним слугувати маловпливовим партіям, які наразі знаходяться на узбіччі великої політики. Зниження прохідного бар'єра сприяло б ще більшому зростанню чисельності парламентських партій, однак не призвело б до безумовного зростання демократичності у прийнятті державних рішень. Очевидно, що зниження прохідного бар'єра стало спробою провести рішення в інтересах не усього литовського суспільства, а лише окремих політичних сил, зокрема, до парламенту в перспективі могли б пройти політичні сили, які не поділяють цінності ліберальної демократії.

Дефекти демократії в Литві мають низку й інших проявів, наприклад, нецивілізоване лобіювання, корупція на різних рівнях - від політичної до побутової та ін. Зокрема корупція вже довготривало $є$ найбільшою проблемою демократичного розвитку Литви. Корупційні викриття 2016-2017 років, судові процеси над на той час провідними політичними партіями країни (Ліберальний рух Литовської Республіки, Партія праці) призвели до критичної втрати довіри населення до багатьох впливових а́кторів литовської політики.

Непрозорі механізми лобіювання фіксуються в Литві попри те, що від 2001 року інститут лобізму $\epsilon$ законодавчо унормований. Зафіксовані факти просування великими литовськими корпораціями своїх інтересів зі застосуванням тиску на депутатів Сейму, інструментів неправомірної вигоди та шантажу. Міжнародний резонанс мали корупційні справи, пов'язані з литовськими філіями іноземних банків «Swedbank», «DanskeBank», «Nordea», литовськими банками «Snoras», «Ūkio bankas» та ін. Загалом корупція (особливо - топкорупція, політична корупція) недостатньо стримується в Литві, а корупційний прагматизм на побутовому рівні ще характерний для литовців.

На якості литовської демократії позначаються прояви нетерпимості до різноманітних меншин (національних, сексуальних та ін.), що суперечить цінностям неоліберальної демократії. Дискримінованими групами, найперше, є литовські роми, представники ЛГБТІ-спільноти, біженці та ін. Останніми роками фіксується наростання антисемітизму. Дискриміновані групи стають, найперше, жертвами мови ненависті та протиправних дій, скоєних на грунті мови ненависті. I хоч на інституційному рівні Литва докладає антидискримінаційних зусиль, узгоджених з політикою ЄС, однак стійкість політики запобігання та протидії різноманітним дискримінаціям підривається низькою громадською підтримкою та проявами інтолерантності з боку громадян.

Очевидними $є$ глибоко вкорінені в литовців забобони та поява новітніх етнічних стереотипів, наявний страх перед імміграцією, що сприяє поширенню ксенофобії, гомофобії, мігрантофобії, ромофобії та ін. Не виключаємо, що застереження перед «людьми ззовні» (мігрантами, біженцями) корениться в історичному минулому Литви. «Інші» все ще викликають страх перед можливою окупацією, нав’язуванням відмінних соціокультурних моделей поведінки тощо.

У частині інтолерантності щодо сексуальних меншин литовська спільнота незмінно дотримується консервативної позиції в питаннях шлюбу та сім’ї. Вважаємо, що нинішні зусилля литовських державних інституцій зі запобігання поширенню неорасистській, гомо-/трансфобній та іншій мові ненависті не можна схарактеризувати як ефективні.

Комплекс проблем, які визначально впливають на якість демократії в Литві, має перспективу загострення найближчим часом на тлі висхідних соціально-економічних проблем урезультаті глобальної пандемії COVID-19. Не виключене поглиблення кризи неоліберально-демократичних цінностей і радикалізація литовської політики. Це може увиразнитися в результатах виборів до Сейму (заплановані на 11.10.2020р.). Очевидно, що в умовах пандемії ця електоральна кампанія проходитиме за жорстких обмежень прав як кандидатів на виборні посади, так і виборців, а результати цих виборів будуть узалежнені від масштабів соціально-економічної кризи та реакції литовського уряду та парламентських партій щодо протидії інфікуванню населення та запобігання руйнівним для економіки та соціальної сфери наслідкам вимушених карантинних заходів.

Восени 2020 року литовську демократію чекає випробування на зрілість: результати виборчої кампанії, проведеної на тлі глобальної пандемії та їі руйнівного впливу на соціально-економічну сферу, покажуть, наскільки стійкими є цінності демократії, прав людини у литовців, наскільки відповідною $€$ їх політико-правова культура ліберально-демократичному типу. На нашу думку, хоча вплив неліберальних політичних акторів у Литві досі був мінімальним, ерозія партійної системи в поєднанні з нездатністю LVŽS_підтримувати високу довіру до технократичного уряду C. Скверняліса створює нішу для приходу до влади інших політичних сил, зокрема й радикальних, 
популістських. Вибори до парламенту в жовтні 2020 року підтвердять або ж спростують цю нашу гіпотезу. Нині ж соціально-політичний клімат для приходу до влади неліберальних політичних сил $\epsilon$ дуже сприятливий, адже в умовах пандемії COVID-19 відбувся значний економічний спад, сильно зросло безробіття, скоротилися доходи населення тощо. На результати чергових парламентських виборів та розкла́д політичних сил в країні сильно вплине оцінка громадянами ефективності дій уряду (найперше від 16.03.2020 р., коли були введені карантинні заходи в країні), його діалогу 3 громадою, підтримка бізнесу та нужденних прошарків, реагування на деструктивні зміни на ринку праці тощо. Саме нині населення дуже чутливо реагує на політику чинного уряду та керівних партій і це неминуче позначиться на результатах чергових парламентських виборів.

Отже, вважаємо, що нині на інституційному та ціннісному рівнях Литва не уповні відповідає ліберально-демократичному стандарту ЄС. Проблема якості демократії має перспективу загострення найближчим часом, особливо на тлі деструктивних соціально-економічних наслідків пандемії COVID-19. Виконавши необхідні вимоги для прийняття до $€ C$, Литва після завершення євроінтеграційного процесу увійшла в фазу стагнації ліберально-демократичних перетворень i потребує більш активної позиції інституту держави щодо інституційних реформ і ресоціалізації громадян у напрямку зміцнення прихильності до тих політико-правових цінностей, на утвердження яких спрямований ЄС. Якість демократії в Литві, на нашу думку, узалежнена від невисокого рівня активізму громадянського суспільства, характеристик політико-правової культури населення, яка наразі потребує зміцнення сегмента ліберально-демократичних цінностей та посилення діалогу влади з громадянами. Для литовців наразі характерна невисока виборча активність і слабкий громадсько-політичний активізм. Подолання цих негативних тенденцій спільно з поглибленням інституційних реформ $є$ основою для поступального розвитку ліберальної демократії в Литві.

\section{References:}

1. Aleknonis, G., Matkevičienè, R. (2016). Populism in Lithuania: defining the research tradition. Baltic Journal of Law \& Politics, 9 (1), 26-48. [in English].

2. Jaruševičiūtè, G. (2020). Reitingai: pasitikèjimas demokratija šalyje paaugo, tačiau vis dar išlieka žemas [Ratings: Confidence in democracy in the country has grown but still remains low].

$<$ https://www.delfi.lt/news/daily/lithuania/reitingai-pasitikejimas-demokratija-salyje-paaugo-taciau-vis-dar-isliekazemas.d?id=83771521> (2020, April, 19). [in Lithuanian].

3. Lytvyn, V. (2012). Populistski partii u strukturi modernykh partiinykh system krain Tsentralnoi Yevropy: porivnialnyi analiz [Populist parties in the structure of modern party systems in Central Europe: a comparative analysis]. Osvita rehionu: politolohiia, psykholohiia, komunikatsii [Education in the region: political science, psychology, communications], 2, 69-77. [in Ukrainian].

4. Oskolkov, P. V. (2019). Pravyj populizm v Evropejskom soyuze [RightWing Populism in the European Union]. Moscow: Institute of Europe. [in Russian].

5. Pabiržis, D. (2013). Populistinès ideologijos partijos Baltijos šalyse 2011-2012 m. [Populist ideology parties in the Baltic States in 2011-2012]. Politikos mokslu almanachas [Almanac of Political Science], 14, 115-137. [in Lithuanian].

6. Ramonaite, A., Ratkevičiūtè, V. (2013). The Lithuanian Case: National Populism Without Xenophobia. In: Exposing the Demagogues: Right-Wing and National Populist Parties in Europe. Berlin: KAS. [in English].

7. Romaniuk, A. S., Lytvyn, V. S., Panchak-Bialoblotska, N. B. (2014). Populistski partii u strukturi modernykh partiinykh system krain Tsentralnoi Yevropy: porivnialnyi analiz [Political Institutes of Central and Eastern Europe: A Comparative Analysis]. Lviv: Lvivskyi natsionalnyi universytet imeni Ivana Franka. [in Ukrainian].

8. Standartinis Eurobarometras 90. Šalies ataskaita. Lietuva. Visuomenès nuomoné Europos Sajungoje [Standard Eurobarometer 90. Country report. Lithuania. Public opinion in the European Union] (2018).

$<$ file:///D:/Media/Downloads/ eb90_nat_lt_lt.pdf $>$ (2020, May, 17). [in Lithuanian].

9. Stašienè, J. (2016). Populist Discourse on Political Representation: A Case Study of Anti-Establishment Organizations in Lithuania. Baltic Journal of Political Science, no 5, 54-72. [in English].

10. The National Security Threat Assessment (2020). Vilnius: Second Investigation Department under the Ministry of National Defence (AOTD) and the State Security. [in English].

11. Tyrimo. Ar Jüs pasitikite, ar nepasitikite šiomis Lietuvos institucijomis? (2020).

$<$ http://www.vilmorus.lt/index.php?mact=News,cntnt01,detail,0\&cntnt01 articleid=2\&cntnt01 returnid=20> (2020, April, 29). [in English]. 